\title{
Endokrin sebészet a Semmelweis Egyetem I. sz. Sebészeti Klinikáján
}

\author{
HORÁNYI JÁNOS, SZLÁVIK REZSÖ, FEKETE KRISZTINA, SZIJÁRTÓ ATTILA
}

Semmelweis Egyetem, I. sz. Sebészeti Klinika, Budapest

\begin{abstract}
A Budapesti Orvostudományi Egyetemen Rubányi Pál a III. és II. Sebészeti Klinika igazgatása után 1963-tól 1975-ig vezette az I. sz. Sebészeti Klinikát. A sebészet igen széles palettáját müvelte, és ezen belül az endokrin daganatok sebészi gyógyításában szerzett tapasztalatairól közleményekben számolt be, valamint a pajzsmirigy sebészetével kapcsolatos disszertáció is készült a klinikán. Utóda, Szécsény Andor 1975-1990 között vezette a klinikát, az endokrinmütéti tevékenysége a mellékvese-sebészetben volt kiemelkedő, erről jelentek meg dolgozatai. Az ő igazgatása alatt jöttek létre az I. sz. Sebészeti Klinika országos hatáskörü szakprofiljai, köztük az endokrin sebészet, melynek megalapítója és első vezetője Alánt Oszkár volt. Irányításával kialakítottuk a klinika endokrin sebészeti betegeinek prospektív nyilvántartó rendszerét, kezdetben lyukkártyás, majd számítógépes módszerrel. A klinikum mellett kísérleti laboratóriumot is létrehozott, ahol OTKA-támogatással elsősorban a pancreas-szigetsejtek transzplantációjával foglalkoztunk. Közlemények mellett az itteni munkából kandidátusi értekezés is készült. Ebben a laborban alakítottuk ki a totál parathyroidektomia és autotranszplantáció mellett végzendő mellékpajzsmirigy-szövet krioprezervációs technikai feltételeit. 1985-ben, néhány hónappal Alánt Oszkár korai halála után, Mérei János végezte el sikeresen az első ilyen mütétet. Mérei 6 évig vezette az endokrin profilt, nevéhez füződik a rutinszerü pajzsmirigy aspirációs citológiai vizsgálat bevezetése a klinika gyakorlatába.
\end{abstract}

1991 óta az endokrin profil vezetője Horányi János volt, a tisztet 2020-ban munkatársa, Szlávik Rezső vette át. Több eljárást elsőként honosítottunk: 1997-ben végeztük az első bal oldali laparoszkópos adrenalektomiát, és azóta mellékvesemütéteink nagy többségét (75-80\%-át) ezzel a technikával operáljuk. 1999 óta rutinszerüen végezzük az intraoperatív parathormon (PTH) meghatározást, 2000 óta a gammaszondás mellékpajzsmirigy-adenomalokalizálást, 2006 óta mütéti szöveti szivadékokból is PTH-meghatározást. Utóbbinak bevezetését a csak vérböl végzett intraoperatív PTH-mérés általunk felismert hibalehetöségének kivédése tette szükségessé: a PTH-szint akkor is leesik, ha a mellékpajzsmirigy-adenoma nem kerül eltávolításra, csak a vérellátása szünik meg. A duplex intraoperatív PTH-meghatározás mellett mellékpajzsmirigy-mütéteink eredményessége 98\%-ra nőtt. (2006-2019: 1306 mütét, az országos műtéti szám 45\%-a). 2000-től néhány esetben videoasszisztált parathyroidektomiát (VAP) is végeztünk.

A klinika pancreas profiljával közösen a pancreas és egyéb hasi szervek neuroendokrin-tumorait is rendszeresen operáljuk, ennek kapcsán intraoperatív ultrahang segítségével sikerült a kis pancreaselváltozások megtalálásában nagy biztonságot elérni. Válogatott esetekben laparoszkóppal is operáljuk a hasnyálmirigy neuroendokrin-tumorait.

$\mathrm{Az}$ endokrin sebészet eredményességében igen fontos szerepe van a társszakmákkal való szoros együttmüködésnek és rendszeres konzultációnak. A lokalizációs diagnosztikában elsősorban az SE Radiológiai Klinikával kooperálunk. A mütét alatti PTH-meghatározás bevezetését a Duffek László (SE Radiológiai Klinika) által kidolgozott, gyorsított inkubációjú radioimmun módszer tette lehetővé. A klinika aneszteziológusai tudományos igénnyel végzik az endokrin betegek ellátásának speciális faladatát. A mütéteknél eltávolított endokrin szövetek közül a pajzsmirigytumorok az SE I. sz. Belklinikáján és a mellékvesék az SE II. sz. Belklinikáján végzett tudományos (elsősorban molekuláris genetikai) feldolgozása több új megfigyelést eredményezett. Amennyiben szükséges, a posztoperatív szakban az SE Belklinikáin végzik a radiojódkezelést, a hormonális utóvizsgálatokat és hormonszubsztituciós beállításokat is.

Profilunk további erősödését várjuk az Egyetemünkön újonnan megalakult Endokrinológiai Tanszékkel való szoros együttmüködéstöl. Az intraoperatív diagnosztika fejlesztése érdekében kezdeményezzük gyors parathormonmeghatározó készülék beállítását a mütőben. Terveink között szerepel, támaszkodva az egyetemi képalkotó diagnosztika széles spektrumára, az endoszkópos minimál invazív pajzsmirigy-, mellékpajzsmirigy-mütétek bevezetése is.

\section{Irodalomjegyzék}

${ }^{1}$ Alánt O, Bodnár A: Hyperinsulismus: Einwirkung des Pancreasinsuloms und dessen Entfernung auf das Blutgerinnungssystem. Acta Chir. Acad. Sci. Hung. 1972; 13: 367-374.

2 Alánt O, Horányi J, J. Nagy É, Farkas A, Weltner Hámori $K$ : Fragen zur Transplantation von Langerhans-Inseln: 
Der Einschluss von lebenden Zellen in ein Polymer, welches eine netzförmige Struktur bildet. Z. Exper. Chirurg. 1982; 15: 138-145.

${ }^{3}$ Balla B, Tobiás B, Kósa JP, Podani J, Horváth P, Nagy Z, Horányi J, Járay B, Székely E, Krenács L, Árvai K, Dank M, Putz Z, Szabó B, Szili B, Valkusz Z, Vasas B, Győri G, Lakatos P, Takács I: Vitamin D-neutralizing CYP24A1 expression, oncogenic mutation states and histological findings of human papillary thyroid cancer.

${ }^{4}$ Journal of Endocrinological Investigation 2015; 38: 313-321.

${ }^{5}$ Darvas K, Pulay I, Megyaszai S, Alánt O, Bihari I: Különböző típusú általános érzéstelenítés hatása a keringésre és a sav-basis egyensúlyra phaeochromocytoma sebészeti kezelése során. Magyar Sebészet 1980; 33: 1-7.

${ }^{6}$ Darvas K, Pinkola K, Tarjányi M, Horányi J, Szücs J: Általános érzéstelenítés secunder hyperparathyreosis mütéte során. Aneszteziológia és Intenzív Terápia 1992; 22: 87-95.

${ }^{7}$ Horányi J, Mérei J, M. Keszthelyi L, B. Kiss I, Hídvégi $J$ : Surgical treatment of secondary hyperparathyroidism by total parathyroidectomy and autotransplantation. M. Sebész T. Kongr. Budapest, 1986, Abstracts p. 22.

${ }^{8}$ Horányi J: Bioarteficiális pankreász és egyéb endokrin szövetek kísérletes és klinikai transzplantációja. Kandidátusi értekezés, Budapest, 1987.

${ }^{9}$ Horányi J, Gerö L, B. Kiss I, Duffek L, M. Keszthelyi L, Pajor A: Bioartificial pancreas: in vitro studies, allo- and xenotransplantation. Diabetes 1989; 38 (Suppl. 1): 299.

${ }^{10}$ Horányi J, Gerö L, B. Kiss I, M. Keszthelyi L, Berczeli M, Kerényi T, Duffek L: Bioarteficiális pankreász. Magyar Sebészet 1990; 42: 148-152.

${ }^{11}$ Horányi J, Tihanyi T, Darvas K, Rácz K, Fütö László: Laparoszkópos adrenalectomia. Orvosi Hetilap 1998; 139: 1689-1691.

${ }^{12}$ Horányi J, Horváth Cs, Lakatos P, Szathmári M, Forgács A, Szlávik R, Szücs J, Flautner L: Az osteoporosis-szürés jelentősége a primer hyperparathyreosisban szenvedők felismerésében. 1999; Ca és Csont 2: 109-112.

${ }^{13}$ Halászlaki Cs, Tobiás B, Balla B, Kósa JP, Horányi J, Nagy Zs, Speer G, Járay B, Székely E, Istók R, Székely T, Putz Z, Dank M, Lakatos P, Takács I: Predictive value of somatic mutations for the development of malignancy in thyroid nodules benign by cytopathology. Endocrine Practice 2016; 22: 1081-1087.

${ }^{14}$ Horányi J, Szlávik R, Duffek L, Csapó Zs, Kemenes M, Dabasi G, Tarjányi M, Szücs J: Video-asszisztált parathyroidektomia. Magyar Sebészet 2000; 53 (Suppl.): 16.

${ }^{15}$ Horányi J, Duffek L, Darvas K, Szlávik R, Pinkola K, Dabasi G, Horváth Cs: Mütét alatti új diagnosztikus módszerek a mellékpajzsmirigy-sebészetben: Intraoperatív parathormonszint-ellenőrzés. Orvosi Hetilap 2001; 142: 1327-1329.

${ }^{16}$ Horányi J, Duffek L, Szlávik R, Darvas $K$, Lakatos $P$, Tóth M, Rácz K: Parathyroid surgical failures with misleading falls of intraoperative parathyroid hormone levels. J. Endocrinol. Invest. 2003; 26: 1095-1099.
${ }^{17}$ Horányi J, Duffek L, Kemenes M, Szlávik R, Darvas K, Dabasi $G$, Lakatos $P$, Tóth $M$ : Új, intraoperatív diagnosztikus módszerek a mellékpajzsmirigy-sebészetben: gamma-szondás adenoma-lokalizáció. Orvosi Hetilap 2005; 146: 1443-1446.

${ }^{18}$ Horányi J, Szlávik R, Duffek L, Darvas K, Györke T, Lakatos $P$, Tóth $M$ : A primer hyperparathyreosis sebészi kezelése. Orvosi Hetilap 2006; 147: 2347-2351.

${ }^{19}$ Horányi J, Duffek L, Szlávik R, Takács I, Tóth M, Romics $L J r$ : Intraoperative determination of PTH concentrations in fine needle tissue aspirates to identify parathyroid tissue during parathyroidectomy. World Journal of Surgery 2010; 34: 538-543.

${ }^{20}$ Horányi J, Lakatos P: Parathyreoidea. In: Kásler $M$ (szerk.): Az onkológia alapjai. Medicina, Budapest, 2011; 1083-1087.

${ }^{21}$ Kokas F : A mütét utáni Basedow-krizisről. Orvosi Hetilap 1948; 89: 61-64.

${ }^{22}$ Horányi J: A hyperthyreosis kezelése - Sebészeti kezelés. In: Lakatos P, Takács I (szerk.): Pajzsmirigybetegségek az orvosi gyakorlatban. SpringMed Kiadó, Budapest, 2017; 96-97.

${ }^{23}$ Horányi J, Lakatos P, Péter I: 51. fejezet - Parathyroidea. In: Kásler Miklós (szerk.): Az onkológia alapjai (egyetemi tankönyv) Medicina Könyvkiadó, Budapest, 2018; 1229-1234.

${ }^{24}$ Kocsis-Deák B, Árvai K, Balla B, Tóbiás B, Kohánka A, Járay B, Horányi J, Podani J, Takács I, Putz Zs, Kósa J, Lakatos $P$ : Targeted Mutational Profiling and a Powerful Risk Score as Additional Tools for the Diagnosis of Papillary Thyroid Cancer. Pathology \& Oncology Research 2020; 26: 101-108.

${ }^{25}$ Kokas F, Csernohorszky V: Basedow-kóros betegek korszerü érzéstelenítése. Orvosi Hetilap 1959; 100: 1219 1224.

${ }^{26}$ Kokas F, Zsebök Z: A mellékvese és vese perirenalis levegőbefúvással való röntgenábrázolásának új módszere. Honvédorvos 1950; 2: 257-261.

${ }^{27}$ Lazarits J, Alánt O: Hyperthyreosis szerepe a mellékvesekéreg elégtelenség létrejöttében. Orvosi Hetilap 1959; 100: 652-655.

${ }^{28}$ Mérei J, Hársing J: Pajzsmirigy elváltozások vékonytü aspirációs citológiai vizsgálatának diagnosztikai értéke. Morphol Igazságügyi Orv. Sz. 1984; 24: 288-293.

${ }^{29}$ Mérei J, Hársing J, Horányi J: Az aspirációs vékonytűbiopszia diagnosztikus értéke pajzsmirigybetegeken: 700, mütéttel ellenőrzött eset alapján. M. Endokrin. Anyagcsere T. XII. Kongr. Budapest, 1988. E-33.

${ }^{30}$ Mundi B: Streoidok jelentősége a hyperthyreosis sebészetében. Kandidátusi értekezés, Budapest, 1973.

${ }^{31}$ Németh É, Orbán I: A hyperparathyreoidizmusról három operált parathyreoideaadenoma-eset kapcsán. Magyar Sebészet 1959; 12: 238-247.

${ }^{32}$ Rubányi P, Keltai $P$ : Unsere Erfahrungen in der Chirurgie des Phaeochromocytoms. Zentrablat für Chirurgie 1964; 89: 1768-1775.

${ }^{33}$ Rubányi P, Keltai P: Our experience on hyperparathy- 
roidism with adenomatosis. Minerva Medica 1970; 61: 82-90.

${ }^{34}$ Rubányi P, Keltai P, Szloboda J: Tapasztalataink a phaeochromocytoma sebészetében. Orvosképzés 1972; 47: 275-281.

${ }^{35}$ Rubányi P, Siklós I: Chirurgische Behandlung der Insulome. Zentrablat für Chirurgie. 1972; 97: 1153-1161.

${ }^{36}$ Sereg M, Töke J, Patócs A, Varga I, Igaz P, Szücs N, Horányi J, Pusztai P, Czirják S, Gláz E, Rácz K, Tóth M: Diagnostic performance of salivary cortisol and serum osteocalcin measurements in patients with overt and subclinical Cushing's syndrome. Steroids 2011; 76: 38-42.

${ }^{37}$ Szabó D, Gyévai A, Gláz E, Stark E, Péteri M, Alánt $O$ : Changes in the fine structure and function of a hormone-secreting adrenocortical tumour investigated in tissue culture. Wirchows Arch. A. Pathol. Anat. Histol. 1975; 367: 273-280.

${ }^{38}$ Szabó DR, Luconi M, Szabó PM, Tóth M, Szücs $N$, Horányi J, Nagy Z, Mannelli M, Patócs A, Rácz K, Igaz $P$ : Analysis of circulating microRNAs in adrenocortical tumors. Laboratory Investigation 2014; 94: 331-339.

${ }^{39}$ Szécsény A, Alánt O, Horányi J, Darvas K, Dabasi G, Berentei E, Szende B, Kiss R, Rácz K, Varga I, Gláz E: A primer aldosteronismus sebészi kezelésének eredményei a praeoperativ diagnózis és a mellékvese morphologia retrospectiv elemzése alapján. Orvosi Hetilap 1985; 126: 2139-2151.
${ }^{40}$ Szendei Á, Virányi A, Komáromy J, Szécsény A, Barta L, Soós I: Tapasztalataink a phaeochromocytoma diagnosztikájában és kezelésében. Orvosi Hetilap 1956; 97 : 316-319.

${ }^{41}$ Szlávik R, Horányi J, Tihanyi T, Bukovácz R, Darvas $K$ : Laparoscopic adrenalectomy. New experiences. Acta Chirurgica Hungarica 1999; 38: 209-211.

42 Tóbiás B, Balla B, Kósa PJ, Horányi J, Takács I, Bölöny E, Halászlaki Cs, Nagy Zs, Speer G, Járay B, Székely E, Istók R, Lakatos P: Szomatikus onkogén mutációk összehasonlító vizsgálata egészséges és tumoros pajzsmirigyszövetmintákban. Orvosi Hetilap 2011; 152: 672-677.

${ }^{43}$ Tóbiás B, Halászlaki Cs, Balla B, Kósa JP, Árvai K, Horváth P, Takács I, Nagy Zs, Horváth E, Horányi J, Járay B, Székely E, Székely T, Györi G, Putz Z, Dank M, Valkusz $Z s$, Vasas B, Iványi B, Lakatos P: Genetic alterations in Hungarian patients with papillary thyroid cancer. Pathology and Oncology Research 2016; 22: 27-33.

${ }^{44}$ Vallent K, Mundi B, Perner F: On the effect of thyroidectomy, as well as thyreotrophic hormone and thyroxin treatment on the serum heparin content and on the leukocyte and eosinophil count. Endokrinologie 1966; 50(1): 57-66.

45 Winternitz T, Flautner L, Tihanyi T, Bursics A, Horányi J: Pre- and intraoperative localisation of endocrine pancreatic tumors. Hepato-Gastroenterology 1992; 39 (Suppl.): 43.

A cikk a Creative Commons Attribution 4.0 International License (https://creativecommons.org/licenses/by/4.0/) feltételei szerint publikált Open Access közlemény, melynek szellemében a cikk bármilyen médiumban szabadon felhasználható, megosztható és újraközölhetö, feltéve, hogy az eredeti szerző és a közlés helye, illetve a CC License linkje és az esetlegesen végrehajtott módosítások feltüntetésre kerülnek. (SID_1) 